DOI: $10.17516 / 1997-1370-0435$

УДК $332.14=111$

\title{
Modern Transdisciplinary Regionology: the Goal and the Objectives
}

\author{
Evgeny V. Kremnyov, Ekaterina V. Lesnikovskaya \\ and Olga V. Kuznetsova* \\ Irkutsk State University \\ Irkutsk, Russian Federation
}

Received 30.05.2019, received in revised form 04.07.2019, accepted 16.07.2019

\begin{abstract}
The main purpose of the research results presented in this article is an attempt to define the goal and the objectives of the new discipline - transdisciplinary regionology, taking into consideration the experience of Russian and foreign schools. The subject of the research is approaches to defining goals and objectives of regional studies in different schools. To study these approaches, the authors use systemic analysis, comparative analysis, conceptual analysis and terminological analysis as the main methods. The article covers the process of establishing a new scientific discipline, which unites the achievements of different disciplines that focus on studying regions and regional processes. The authors substantiate transdisciplinarity as its basic characteristic and explain the choice of the term "regionology". The results of the work are applicable in the process of theoretical development of terminology and methodology of regional studies as well as in planning applied works in this field. In the conclusion of the article, the authors infer that the main goal of transdisciplinary regionology is to define the laws of uneven development of world regions basing on the transdisciplinary approach and the scientific-pragmatic experience of the region or group of regions under study, which determines its specific objectives.
\end{abstract}

Keywords: regional science, region studies, region, country studies, problem-based area studies, country studies, World Complex Region Studies, sociocultural region studies, global studies, regionology, transdisciplinary regionology.

The reported study was funded by Russian Foundation of Basic Research according to the research project No. 19-011-00040 "History and methodology of Asia Pacific region studies in the framework of modern transdisciplinary regionology".

Research area: transdisciplinary research.

(C) Siberian Federal University. All rights reserved

* Corresponding author E-mail address: kremnyov2005@mail.ru; elesnikovskaya@gmail.com; kuznetsova1@mail.ru 
Citation: Kremnyov, E.V., Lesnikovskaya, E.V., Kuznetsova, O.V. (2019). Modern transdisciplinary regionology: the goal and the objectives. J. Sib. Fed. Univ. Humanit. Soc. Sci., 15(4), 443-452. DOI: $10.17516 / 1997-1370-0435$.

\section{Introduction}

The importance of studying a region, its specific features, the factors and perspectives of its development in the modern world is hard to overestimate. The need for such studies is substantiated by the most important trends of interregional relations - the processes of regionalization and globalization, which, as many researchers believe, develop as two dynamic processes influencing each other (Plotnikova, Dubrovina, 2013: 135). In the center of this mutual influence are the regions that possess a variety of resources and are able to become a crossing point for the main economic ways and interactions of different countries, taking advantage of their geographical position, they become a center of attraction of foreign partners (Plotnikova, Dubrovina 2013: 136). For the regions that have not become such centers, studying its own experience as well as the experience of other regions' development comes as a challenge and a growing point, allowing taking into consideration the negative factors that slow down regional development and using the region's advantages to reach the desired level of political, economic and social development.

\section{Theoretical framework}

The idea that a region must be an object of an independent discipline, has been formed by 1950 -s. By that time, the USSR had already had Soviet zoning school (районная школа), the theory for which had been written by N. Baranskiy (Baranskiy, 1926; 1928), the basics of economic zoning were formed (Kolosovskiy, 1958); however, these disciplines developed in the framework of economic development. Meanwhile, a new scientific community was developing on the basis of American Economics Association - Regional Science Association. Its first independent planning meeting took place in December 1954 (Isard, 2003: 75). The founder of the discipline was an economist and geographer W. Isard. Little by little, the branches of the association opened in all over the world, constituting the network of Regional Science Association International. On the whole, research activities of this school remain to be of economic-geographic nature.

In the second half of the $20^{\text {th }}$ century and at the beginning of the $21^{\text {st }}$ century the goals and objectives of region studies in foreign science were conducted, in particular, in the framework of such disciplines as Regional Science and Area Studies. In Russian science, region studies were conducted in the framework of various schools that relied each on their own basic principles. In general, this results in adherence to a certain discipline, which uses the methodology and terminology of other disciplines as well; in some cases, this results in using an interdisciplinary approach at the joint of two or three disciplines. In this way, economicgeographic traditions are supported by Problem-based Country Studies (проблемное страноведение) (Ya. Mashbitz, V. Gokhman). Global Studies (A. Utkin, M. Cheshkov, M. Delyagin, V. Leybin, A. Chumakov, V. Inozemtsev etc.) are defined as a new philosophy of the globalizing world, "a conceptual science that expresses a true philosophical approach, a truly philosophical examination of the global world around us" (Vasilescu, 2010: 22). Such studies as Region Studies (регионоведение) (Yu. Gladkiy, A. Chistobaev, V. Dergachyov, L. Vardomskiy, Yu. Volkov, V. Ignatov, V. Butov, T. Morozova, M. Ivanova, M. Shtan'ko, M. Sharygin, Yu. Abramov, I. Barygin, I. Pavlovskiy, V. Naumenko) and regionalism studies (регионалистика) (N. Zubarevich, E. Vavilova, D. Lopatnikov, E. Kuz'bozhev, I. Koz'eva) for a long time could not relate to other disciplines, in inclination sometimes to Economic Geography, sometimes to Political Science, sometimes to other regional disciplines. Recently, attempts have been made to institutionalize regional science and define its place and role in the system of other disciplines. In particular, A. Voskresenskiy and his colleagues 
(A. Baykov， V. Belokrenitskiy， A. Ermolaev, E. Koldunova, A. Kireeva) propose to consider World Complex Region Studies and Comparative World Politics to be the new subjects of the International Relations discipline (Voskresenskiy, 2013: 95).

\section{Statement of the problem}

The current state of regional studies can be characterized with the following problems:

1) the ambiguity of the term that names the discipline, both in Russia and abroad;

2) the ambiguity of the place of the discipline among other disciplines;

3) the ambiguity of the goals, the objectives, the subject and the methodology.

It is obvious from what has been said above that in the modern science there has arisen the need to, on the one hand, combine different approaches to studying regions, thus providing an opportunity of a complex, systematic examination of the object of the study. On the other hand, there has arisen the need to maintain the trend of transdisciplinarity by including the methods and tools of all sociohumanitarian disciplines (both those basic for it and those that have been long aside) into the theory and methodology of the new discipline. In particular, this role can be played by transdisciplinary regionology.

The proposed term contains an attempt to solve the first two problems from the three listed above. Firstly, the term "Regionology", so far not so frequently used in Russian scholarly discourse as "Region Studies", provides a deeper reflection on the processes of forming an academic discipline - as opposed to the entity of accumulated knowledge about the object of research - "in Russian, the part of the world -логия (-logy) - from names of disciplines such as "seismology", "parasitology", "nutriology" etc. - is usually associated with the type of knowledge in which deductive conclusion can be drawn basing on the given data and the logical structure of the knowledge" (Rozhdestvenskiy, 1996: 3). Secondly, the term points to transdisciplinarity as the basic characteristic of the discipline, which allows employing a com-

\footnotetext{
Here and further all quotations from non-English-speaking sources are translated by the authors of the article.
}

plex approach to the analysis of the development of a region using preceding achievements of all the region studies disciplines and taking advantage of the new research and theories.

\section{Methods}

The subject of the research is approaches to defining goals and objectives of regional studies in different schools. To study these approaches, the authors use systemic analysis, comparative analysis, conceptual analysis and terminological analysis as the main methods.

\section{Discussion}

The definition of the goals, the objectives, the object, the subject, and the methodology of transdisciplinary Regionology can be done by having first analyzed the experience of the existing disciplines that focus on studying regions from different angles.

In Russian science, there exist several interrelated approaches to the goals and objectives of disciplines that focus on region studies:

1) on the basis of distinguishing region studies from other disciplines;

2) reliance on one or several disciplines as a basis for region studies development;

3 ) on the basis of the paradigm the researcher has accepted.

As for the first approach of the listed above, defining the objectives of a discipline that focuses on regions on the basis of distinguishing it from other disciplines takes place because, despite their respectful age, region studies are "young" in comparison to other disciplines. This approach has been used in the work of I. Rutsinskaya, who sees the objectives of region studies - unlike those of Local Areas Studies (краеведение) with its local and empiric character - as to see the specifics of the region, differentiate it from other regions, include the region into a more global system, try to explain the laws of territorial development (Rutsinskaya, 2009: 13).

Besides, the objectives of region studies can include synthesizing information on local area grouping countries on the basis of certain criteria (political, economic etc.) (Maksakovskiy, 2004), as well as studying territorial entities where region studies act as an interdisci- 
plinary branch of geography, close to but not equivalent for area studies (Gladkiy, 2002).

Finally, defining the goals and the objectives can be carried out by distinguishing region studies (регионоведение) and regionology (регионология). For instance, V. Naumenko proposes to understand the objectives of regionology as to answer the question what a region is, reveal the basics and the regularities of its development, and the objectives of region studies as to integrate different pieces of knowledge on different spheres of life (Naumenko, 2011: 75).

The second approach that implies reliance on one or several disciplines as a basis for region studies development provides the following definition of the the goals and objectives.

In particlular, A. Voskresenskiy, having substantiated World Complex Region Studies (мировое комплексное регионоведение), states that «the purpose of complex world political and region studies of comparative nature basing on the methodology of comparative political analysis (crossregional political analysis) is to analyze historic events through the prism of complex integrative approaches of analysis of socioeconomic and cultural-political spaces that fix the distances and differentiations in the field of forming, functioning and development of world-political relations») (Voskresenskiy, 2013: 90). In the continuation of the thought, E. Koldunova sees the purpose of world complex region studies to be the explanation of the interrelation between international and intranational/intraregional processes and the study on how the peculiarities of intranational/regional development influence the global level (Koldunova, 2016: 64). The purpose of this discipline is relevant for the problems discussed and focuses on studying a region as an international relations actor.

Quite a different approach to defining the goals and objectives of regional science has been put forward by I. Pavlovskiy. He has brought up the idea of sociocultural region studies, which brings the discipline further away from international relations and closer to, in particular, social anthropology. According to I. Pavlovskiy, the purpose of region studies is to study the priorities and dominants constant for the territory of the given region as well as the "holes" in local culture $^{2}$ that creates gaps not only in word formation but also in the cultural phenomena and concepts (Pavlovskiy, 2014: 109). Moreover, I. Pavlovskiy highlights three basic objectives of region studies:

1) to give a terminologically correct description of the specificity of the properties acquired by the ethnos as a result of its migration to other regions, which will facilitate a more detailed study of the influence of a region over languages and cultures;

2) to concretize the terms used in relation to a region, taking their regional specifics into consideration, since histories of regions often mismatch their descriptions in which more universal terms and concepts have been used;

3) studying the initial specific features of an ethnos, to label as most important those of them that remain constant for the region even if the ethnicities inhabiting it are replaced; to study the distinctive character of a region in the historical retrospective through the prism of the ethnicities that have inhabited it, "to study the destiny of the acquired features of ethnicities that migrated from the region of study to another one" (Pavlovskiy, 2005: 146-148).

As can be seen from the goals and objectives listed above, I. Pavlovskiy considers area studies to be a branch of knowledge at the joint of ethnolinguistics, social anthropology, ethnology, and philosophy.

In a similar way - using grounding of other disciplines - the goals and the objectives of area studies have been described by a number of other scholars. In particular, V. Razumovskiy, D. Sevastyanov refer to Region Studies (регионоведение) and Country Studies (страноведение) as to branches of geography and define the objective of region studies as to form "a complex representation of large regions of the world by uniting pieces of information on groups of countries, their socioeconomic and political ties, the perspectives of in-

\footnotetext{
2 By the "holes" in culture I. Pavlovskiy implies existence of a term but absence of the phenomena in cultural life. He believes a region must be studied not only through the phenomena that are present in the culture of the ethnos inhibiting the region but also through the phenomena that are absent in this culture but present in other regions (Pavlovskiy, 2012).
} 
tegration and disintegration of world economy" (Razumovskiy, 2009: 85).

The socio-economic specifics of regional studies are seen as the most important by A. Obedkov. According to his opinion, the most important objectives of region studies as an analytical and applied science are description, explanation and prediction of regional socio-economic processes and complex characteristics that make up the subject of studies (Obedkov, 2017: 132).

The third paradigm of region studies provides a way to define its goals and objectives in the following way. I. Barygin, defining the terms and the theoretical grounds for regional studies, proposes to base on the interdisciplinarity of regional studies and employ multiparadigmality. Assuming that "region studies, basing on the analysis of proximity of paradigmal rows, are much closer to sociology and political science than to political economy... and international relations theory" (Barygin, 2005: 118), he defines the goals of region studies through the necessity to solve the "basic" problem that depends on the paradigm applied:

- in the classical paradigm - "to explain the necessity of existence of a region";

- in the modernist paradigm - "to understand why the region is this way"; "to show that some regions lead due to a higher level of rationality, the influence of "Protestant ethics", the "correct" culture";

- in the postmodernist paradigm - "to present one's own model of studying a region";

- in the globalization paradigm - "to define the reasons for the global changes of world regions";

- in the gender paradigm - "to define the gender consequences and the reasons for the global changes of world regions" (Barygin, 2005: 119).

In Russian disciplines the interpretations of the gist, the goals and objectives of regional science differ from those of Western scholars. W. Isard, the founder of Regional Science, the first President, later Honorary Chairman of the International Association of Regional Science considers Regional Science to be "...a social science field, focusing upon spaces and systems of spaces, regions and systems of regions, location and system of locations" (Isard, 2003: 187). W. Isard draws attention to the fact that regional science is a social science; it studies, first of all, the human and the forms of special interaction related to human activity. Regional science focuses on behavioral issues and social institutions. According to $\mathrm{W}$. Isard, this is how regional science is different from geography: geography focuses mainly on the physical and biological details of spatial aspects whereas regional science is primarily oriented towards analysis of social processes (Isard, 2003: 187).

Whereas the object of Regional Science is regions of subnational (sub-state) level, the object of Area Studies is countries and groups of countries - macroregions. Area Studies as a field of knowledge and a university discipline arose in the USA in the second half of 1940-s. A rapid development of the discipline was caused by strategic efforts and significant funding; the reasons for the relevance of this sphere of knowledge were the beginning of the Cold War and the related necessity to study the enemy in the War. As N. Smith points out, the reason for such a discipline to appear in the USA was the insufficiency of academic geographic knowledge in this country and, as a consequence, the inability to provide the state with the knowledge about the postwar world (Smith, 2010: 24). J. D. Sideway argues that Area Studies became a way of thinking, when regions are seen as a way to apply combined interdisciplinary theories and, accordingly, a tool of organization of academic knowledge (Sideway, 2012: 4). The end of the Cold War as well as the growth and strengthening of globalization processes in the world have led to the need to rethink and reconceptualize Area Studies. The search for the new paradigm is present in the works of such scholars as D. Ludden, D. Szanton, W. Schafer etc. There is a variety of interpretations of the new paradigm. A number of scholars believe that Area Studies are to develop in the context of globalization processes. For instance, D. Ludden argues that the theory of Area Studies should be reconsidered taking globalization into account (Ludden, 2000). W. Schafer supports the idea and believes that the future of regional science lies in uniting global and 
local studies (Schafer, 2010). D. Szanton offers a different angle: he does not relate the modern paradigm of Area Studies to global studies, considering it an umbrella term for a whole row of academic disciplines that all have five necessary properties. The properties are as follows: language proficiency, field studies of languages, focus on local history and local interpretations, the search for and grounding of a holistic approach to studying a region, multidisciplinary interaction among scholars (Szanton, 2004). The described angle differs from the one Regional Science is usually regarded from and reasonably changes the goals and the objectives of the academic discipline of Area Studies.

In the works of scholars of non-Englishspeaking countries there are authentic trends in defining the goals and the objectives of regional science. In particular, in China such works are explicitly economy-oriented. The goal of a significant number of Chinese regional studies can be generally defined as analysis of the problem of socio-economic misbalance among the regions. Attempts to find solutions as to overcome the misbalance are in regional science works of Chinese scholars such as Bao Yuan (暴元), Wang Xuanxuan (王选选), Wei Yehua (魏也华), Li Zhongyi (李中一), Luo $\mathrm{Yu}$ (罗煜), $\mathrm{Lu}$ Zunhua (卢 遵华)，Wu Peng (武鹏)， $\mathrm{Hu}$ Zhaoliang (胡兆量), Zhang Wei (张玮), Qian Lexiang (钱 乐祥) (Makeeva, 2019: 226).

Shiba Nobuhiro (柴宜弘), a Japanese scholar, a member of the presidium of the Japanese Association for Russian and East European Studies (ロシア・東欧学会) argues that the main objective of regional studies in Japan after World War II has been studying the cultures and societies of countries and regions in order to fully understand them, while in the United States, according to his opinion, Area Studies were initiated with the purpose of studying "the enemy". That is why, as the scholar states, Doctoral Studies in Regional Studies (the program in Cultural Studies Department of Tokyo University that has functioned for over 20 years) are entitled Regional Cultural Studies (地域文 化研究), which emphasizes multidisciplinarity of the discipline; within the framework of the discipline, Culture is viewed broadly, as including various kinds of human activity: politics, economy etc. (Shiba, 2016).

\section{Results}

The heterogeneous definitions offered by scholars and listed above allow making several conclusions that are crucial for further development of regional science.

Firstly, region as the object of studies implies a variety of approaches to studying regional development. Region as the object of studies requires tools of a significant number of disciplines (geography, economics, political science, sociology, philosophy, linguistics, ethnology etc.) and their branches (area studies, local areas studies, economic geography, international relations theory, social philosophy, sociology of regions, ethnolinguistics etc.).

Secondly, more and more scientists turn to the interdisciplinary approach to the study of a region and continue to increase the number of interdisciplinary sub-branches of sciences crossing the boundaries of concrete disciplines and entering the area of transdisciplinarity. L. Kiyashchenko and V. Moiseev explain the difference between the first and the second approach in the following way: "the situation of interdisciplinarity is the situation of transferring the knowledge from one discipline to another one while maintaining disciplinary divide... In other words, interdisciplinarity provides additional methodological enrichment of what is inside inderdisciplinary divide... The situation of transdisciplinarity... implies breaking strict disciplinary divide of scientific knowledge, they become "passable", which facilitates different kinds of systems that are "above" disciplinary divide, "inter"-system entities, "extra" systems etc." (Kiyashchenko, 2010, cit. Lysak, 2014: 135).

Numerous scientific schools and their representatives turn to transdisciplinarity as to a more productive and progressive approach: Edgar Morin Institute of Modern Anthropology in Paris, International Centre for Transdisciplinary Research, in Russian science L. Kiyashchenko, V. Moiseev, E. Knyazeva and others (Lysak, 2014: 135). Presumably, complex study of a region today needs de- 
veloping a theory of transdisciplinarity as one of the most productive approaches to this kind of studies.

Thirdly, the enrichment of the scientific base of region studies should rely upon the experience of different schools and the integration of their achievements into a general methodological area. Such work is being done - in particular, A. Voskresenskiy seeks to construct a non-Western (from China's angle) theory of international relations with the aim to further the study of world regions (Voskresenskiy, 2013). The extension of such an approach and its use in the transdisciplinary area is one of the greatest challenges that regional science faces today.

Basing on the approaches that have been analyzed above and the definition that has been suggested (Makeeva, 2018: 10), we aim to define the gist and the content of transdisciplinary regionology, its goals and objectives.

Transdisciplinary regionology is a science that focuses on the economic and geographic, cultural and historic, sociopolitical and linguistic singularity of regions, defines laws of disproportional regional development in the world community, and relies on the theoretical and methodological base of studies of regional development processes in regions - the objects of study.

As the above mentioned definition implies, the goal of this science is to reveal the laws of disproportional development of the regions of the world basing on the transdisciplinary approach and the scientific-pragmatic experience of the region or group of regions under study. sic ones:

We see the following objectives as the ba-

1) studying the peculiarities of development of economy, politics, society, culture, history, the languages of different regions of the world;

2) on the basis of data on the peculiarities of the region, defining laws and factors of their disproportional development using complex transdisciplinary analysis and theoretical and methodological achievements on the regions under study;

3) assessing the developed, offered and implemented strategies to improve regional economic and sociopolitical systems, forecasting perspectives of regional development.

The first of the objectives helps synchronize in one framework the approaches and tools of disciplines that study a region from different angles: economy, geography, political science, sociology, cultural anthropology, ethnology, history, linguistics etc. The second objective allows developing in the framework of transdisciplinary regionology an independent theory and methodology, enriched by national schools of regional science. The third objective is to solve practical problems of regional development.

The goal and the objectives of transdisciplinary regionology are suggested in this article in a most generalized form and need further correction and extension. With this in mind, we believe that the development of the discipline considered is crucial for further development of the theory of sciences focusing on regions as well as for the promotion of applied research in this sphere.

\section{References}

Baranskii, N.N. (1926). Ekonomicheskaia geografiia Sovetskogo soiuza: Obzor po oblastiam gosplana [Economic geography of the Soviet Union: Review of Gosplan zones]. Moscow, Leningrad, Gos. izd-vo, 294 p.

Baranskii, N.N. (1928). Kratkii kurs ekonomicheskoi geografii [A concise course of economic geography]. Moscow, Leningrad, Gos. izd-vo, 455 p.

Barygin, I.N. (2005). Teoriia mezhdunarodnykh otnoshenii i regionovedenie v kontekste osnovnykh nauchnykh paradigm [Theory of international relations and region studies in the context of the main scientific paradigms]. In Politicheskaia ekspertiza: POLITEKS [Political expertise: POLITEKS], 1 (3), $114-123$.

Gladkiy, Iu.N., Chistobaev, A.I. (2002). Regionovedenie: uchebnoe posobie [Region studies: course book]. Moscow, Gardariki, 384 p. 
Isard W. (2003). History of Regional Science and the Regional Science Association International. The Beginnings and Early History. Berlin, Heidelberg, New York, Springer-Verlag, 267 p.

Kiyashchenko, L.P., Moiseev, V.I. (2010). Filosofiia transdistsiplinarnosti [Philosophy of transdisciplinarity]. Moscow, IF RAN, 205 p.

Koldunova, E.V. (2016). Mirovoe kompleksnoe regionovedenie kak issledovatel'skii podhod i uchebnaia distsiplina [World complex region studies as a research approach and an academic discipline]. In Vestnik MGIMO-Universiteta [Herald of MGIMO University], 50 (5), 63-69.

Kolosovskii, N.N. (1958). Osnovy ekonomicheskogo raionirovaniia [The basics of economic zoning]. Moscow, Gospolitizdat, $200 \mathrm{p}$.

Ludden, D. (2000). Area studies in the age of globalization. In FRONTIERS: The Interdisciplinary Journal of Study Abroad, available at: www.sas.upenn.edu/ dludden/GlobalizationAndAreaStudies.htm

Lysak, I.V. (2014). Mezhdisciplinarnost' i transdistsiplinarnost' kak podhody k issledovaniiu chelove$\mathrm{ka}$ [Interdisciplinarity and transdisciplinarity as approaches to studying a person]. In Istoricheskie, filosofskie, politicheskie i iuridicheskie nauki, kul'turologiia i iskusstvovedenie. Voprosy teorii i praktiki [Historical, political and legal sciences, Culture studies and art studies. Questions of theory and practice], 6 (44), 134-137.

Makeeva, S.B. (2018). Issledovaniia razvitiia regionov v ramkakh transdisciplinarnoi regionologii [Studies of region development in the framework of transdisciplinary regionology]. In Trudy I Mezhdunarodnoij nauchno-prakticheskoi regionovedcheskoi konferencii "Teoriia i praktika regionovedeniya" [Proc I Int. Conf. "Theory and practice of region studies"]. Saint Petersburg, 6-14.

Makeeva, S.B. (2019). Problemy neravnomernogo razvitiia Kitaia v rabotakh kitaiskikh uchenykhregionovedov [The problems of uneven development of China in the works of Chinese region studies scholars]. In Vestnik Volgogradskogo gosudarstvennogo universiteta [Herald of Volgograd State University], Seriia 4, Istoriia. Regionovedenie. Mezhdunarodnye otnosheniia [Series 4. History. Region Studies. International Relations], 24 (1), 225-236.

Maksakovskiy, V.P. (2004). Geograficheskaia karta mira. Obshchaia kharakteristika mira. Regional'naia kharakteristika mira [Geographic map of the world. Basic characteristic of the world. Regional characteristic of the world]. Moscow, Drofa (Vysshee obrazovanie), $318 \mathrm{p}$.

Naumenko, V.E. (2011). Innovatsionnyi podhod v razrabotke modeli vuzovskogo kursa "Regionovedenie" [Innovation approach in the development of university course "Region studies"]. In Kul'turnaia zhizn' Iuga Rossii [Cultural life of Russia's South], 4 (42), 74-78.

Obedkov, A.P. (2017). Severnoe regionovedenie kak nauchnaia i obrazovatel'naia distsiplina: istoriia razvitiia, predmet, soderzhanie [North region studies as an academic and educational discipline: history of development, subject, content]. In Vestnik Komi respublikanskoi akademii gosudarstvennoi sluzhby $i$ upravleniia [Herald of the Republic of Komi Academy of State Service and Management], Seriia: Teoriia i praktika upravleniia [Series: Theory and practice of management], 19 (24), 130-141.

Pavlovskii, I.V. (2005). Regionovedenie segodnia [Region studies today]. In Vestnik Moskovskogo universiteta [Herald of Moscow University], Seriia 19: Lingvistika i mezhkul'turnaia kommunikatsiia [Series 19: Linguistics and intercultural communication], 2, 145-156.

Pavlovskiy, I. V. Vvedenie $v$ regionovedenie: uchebnoe posobie [Introduction to region studies: course book]. Moscow, Tsentr po izucheniiu vzaimodeistviia kul'tur, $199 \mathrm{p}$.

Pavlovskiy, I.V. (2014). Sotsiokul'turnoe regionovedenie kak gumanitarnaia spetsial'nost' (ch. 1.) [Sociocultural region studies as a humanitarian discipline]. In Vestnik Moskovskogo universiteta [Herald of Moscow University], Seriia 19: Lingvistika i mezhkul'turnaia kommunikatsiia [Series 19: Linguistics and intercultural communication], 2, 102-109.

Plotnikova, O.V., Dubrovina, O. Iu. (2013). Globalizatsiia i regionalizatsiia, ikh vliianie na mezhdunarodnoe sotrudnichestvo regionov gosudarstv [Globalization and regionalization, their influence on international cooperation of regions of countries]. In Vlast' [Power], 21 (2), 134-136.

Razumovskiy, V.N., Sevast'ianov, D.V. (2009). Regionovedenie i stranovedenie v strukture geograficheskoi nauki [Region studies and country studies in the structure of geography]. In Vestnik Sankt- 
Peterburgskogo universiteta [Herald of Saint Petersburg University] Seriia 7. Geologiia. Geografiia [Series 7. Geology. Geography], 4, 81-86.

Rozhdestvenskiy, Iu.V. (1996). Vvedenie v kul'turovedenie: ucheb. posobie dlia vuzov [Introduction to culture studies: course book]. Moscow, Chero, 288 p.

Rutsinskaya, I.I. (2009). Regionovedenie i kraevedenie: masshtaby razlichii i formy vzaimodeistvii [Region studies and local areas studies: scale of differences and forms of interaction]. In Vestnik Moskovskogo universiteta [Herald of Moscow University] Seriia 19: Lingvistika i mezhkul'turnaia kommunikatsiia [Series 19: Linguistics and intercultural communication], 3, 9-16.

Schafer W. (2010). Reconfiguring area studies for the global age. In Globality Studies Journal, 22, available at: https://gsj.stonybrook.edu/article/reconfiguring-area-studies-for-the-global-age/

Shiba, N. (2016). Japanese studies as Regional science. In Electronic Journal of Central European Studies in Japan, 2 (In Japanese).

Sideway, J.D. (2012). Geography, globalization and the problematic of area studies. In Annals of the Association of American Geographers, DOI: 10.1080/00045608.2012.660397

Smith, N. (2010). Remapping area Knowledge. Remaking Area Studies: Teaching and Learning across Asia and the Pacific. Honolulu, University of Hawaii's Press, 24-40.

Szanton, D. (2004). The origin, Nature and Challenges of Area Studies in the United States. Berkeley, University of California Press, $340 \mathrm{p}$.

Vasilescu, G. (2010). Metodologicheskie aspekty globalistiki [The methodological aspects of global studies]. In Vek globalizatsii [Age of globalization], 1, 18-29.

Voskresenskiy, A.D. (2013). Mirovoe kompleksnoe regionovedenie i perspektivy postroeniia nezapadnoi (kitaizirovannoi) teorii mezhdunarodnykh otnoshenii [World complex region studies and the perspectives of constructing a non-Western (China-oriented) theory of international relations], In Polis. Politicheskie issledovaniia [Polis. Political studies], 6, 82-96. 


\title{
Современная трансдисциплинарная
}

регионология: цели и задачи

\section{Е.В. Кремнёв, Е.В. Лесниковская, О.В. Кузнецова}

Иркутский государственный университет

Российская Федерация, Иркутск

\begin{abstract}
Аннотация. Основной целью исследования, результаты которого представлены в данной статье, является попытка определить цель и задачи новой научной дисциплины - трансдисциплинарной регионологии - с учетом опыта российских и зарубежных научных школ. Предметом исследования выступают подходы к определению целей и задач региональных исследований в различных школах. Для изучения этих подходов в качестве основных методов авторы используют системный, сравнительный, концептуальный и терминологический анализ. В статье рассматривается процесс формирования нового научного направления, которое объединяет достижения школ, ориентированных на изучение регионов и региональных процессов. Авторы обосновывают трансдисциплинарность как основную характеристику новой научной дисциплины и объясняют выбор термина «регионология». Результаты работы могут быть применены при теоретической разработке терминологического и методологического аппарата в региональных исследованиях, а также при планировании прикладных работ в этой области. В заключении авторы делают вывод о том, что в качестве основной цели трансдисциплинарной регионологии следует постулировать выявление закономерностей неравномерного развития регионов мира на основе трансдисциплинарного подхода с опорой на научно-прагматический опыт исследуемого региона или группы регионов, что определяет формулировку ее конкретных задач.
\end{abstract}

Ключевые слова: региональная наука, регионоведение, регион, страноведение, проблемное страноведение, мировое комплексное регионоведение, социокультурное регионоведение, глобалистика, регионология, трансдисциплинарная регионология.

Исследование выполнено при финансовой поддержке РФФИ в рамках научного проекта № 19-011-00040 «История и методология регионоведческих исследований Азиатско-Тихоокеанского региона в русле современной трансдисциплинарной регионологии».

Научная специальность: трансдисциплинарные исследования. 